\title{
Pengaruh Struktur Modal Terhadap Nilai Perusahaan Pada Perusahaan Manufaktur Sektor Barang Konsumsi Di Bursa Efek Indonesia
}

\author{
SETIAWATI \\ Dosen Tetap Sekolah Tinggi Ilmu Ekonomi Persada Bunda \\ Jln. Diponegoro No. 42 (0761)23181 Pekanbaru \\ E-mail : setiawatieci@gmail.com
}

\begin{abstract}
This study aims to examine and analyze the effect of capital structure on the value of companies in the consumer goods manufacturing sector companies in Indonesia Stock Exchange. This type of research uses quantitative research. This study uses secondary data in the form of corporate financial statements and stock prices. The sample determination using purposive sampling technique. Data analysis using classical assumption test and multiple linear regression. The indicators of capital structure of this study are Debt to Equity Ratio (DER) and Debt to Asset Ratio ( DAR). The company value indicator is Price to Book Value $(P B V)$. The results of the study explain that there is a significant effect simultaneously between DAR and DER on PBV. Partially there is significant DER influence on PBV.
\end{abstract}

Keywords: Capital Structure, Corporate Value

Industri manufaktur merupakan salah satu sektor industri yang mendominasi perusahaan-perusahaan yang terdaftar di Bursa Efek Indonesia (BEI). Tahun 2016 sektor ini salah satu penyumbang investasi terbesar di Indonesia. Agar tetap bertahan maka perusahaan dalam industri tersebut harus semakin meningkatkan kinerjanya guna mencapai tujuan semaksimal mungkin dan mampu bersaing secara global.

Tujuan utama perusahaan adalah untuk memaksimalkan kekayaan atau nilai perusahaan.Artinya,memaksimalkan

kekayaan pemilik perusahaan yaitu pemegang sahamnya. Semakin tinggi harga saham maka semakin tinggi juga tingkat kemakmuran pemegang saham.

Bagi perusahaan yang sudah go public, maka nilai perusahaan akan tercermin dari nilai pasar sahamnya sedangkan bagi perusahaan yang belum go public, maka nilai perusahaan adalah nilai yang terjadi apabila perusahaan tersebut dijual (Harjito dan Martono, 2011).

Perusahaan yang sudah go public pasti membutuhkan dana untuk mengembangkan usahanya dengan memperoleh danadari dalam perusahaan (modal sendiri) atau dari luar perusahaan (modal asing) selain dari hasil usaha atau pendapatan operasi perusahaan. Penggunaan sumber dana jangka panjang seperti hutang jangka panjang, saham baik saham biasa maupun saham preferen, dan laba ditahan yang dilakukan perusahaan akan membentuk struktur modal perusahaan (Kusnaeni, 2012).

Struktur modal menurutHarjito dan Martono (2010:240) adalahperbandingan atau imbangan pendanaan jangka panjang perusahaan yang ditunjukkan oleh perbandingan hutang jangka panjang terhadap modal sendiri.

Sedangkan struktur modal yang dipaparkan oleh Riyanto (2010:22) merupakan pembelanjaan permanen dimana ditunjukkan dengan perimbangan antara modal sendiri dengan hutang jangka panjang.

Jika dalam pendanaan perusahaan yang berasal dari modal sendiri masih mengalami kekurangan (defisit) maka perlu dipertimbangkan pendanaan perusahaan yang berasal dari luar, yaitu hutang (debt financing). Namun dalam pemenuhan kebutuhan dana, perusahaan harus mencari alternatif-alternatif pendanaan yang efisien. Pendanaan yang efisien akan terjadi bila perusahaan mempunyai struktur modal yang optimal. 
Struktur modal yang optimal sangat diperlukan karena dapat mempengaruhi tinggi rendahnya permintaan akan saham dimana hal tersebut juga akan mempengaruhi nilai perusahaan.

Dengan demikian penentuan dalam pengambilan kebijakan struktur modal perusahaanharuslah melibatkan risiko dan tingkat pengembalian (return) karena dengan bertambahnya hutang, risiko dan tingkat pengembalian yang diharapkan perusahaan juga akan bertambah besar.

Untuk itu perlu dilakukan analisis struktur modal dimana dalam penelitian ini variabel yang digunakan adalah Debt to Equity Ratio (DER) dan Debt to Asset Ratio (DAR) dimana mencerminkan perbandingan antara hutang, modal sendiri, dan aset yang dapat dimanfaatkan bagi investor dalammelihat bagaimana resiko dan tingkat pengembalian hutang suatu perusahaan. Jika resiko dan tingkat pengembalian hutang menciptakan pendapatan maka tentuinvestor akan memiliki pandangan positif terhadap perusahaan. Namun jika sebaliknya,ini akan menimbulkan pandangan negatif investor terhadap perusahaan. Dengan demikian kondisi ini tentu saja akan mempengaruhi permintaan saham sehingga juga akan mempengaruhi nilai perusahaan.

Sektor industri barang konsumsi yang merupakan salah satu sub sektor dari perusahaan manufaktur di Bursa Efek Indonesia (BEI) dijadikan sampel dalam penelitian ini karena saham untuk sektor ini selalu menjadi favorit di mata investor sebab Indonesia populasi penduduknya besar dan daya belinya terus meningkat.

Berdasarkan yang dikemukakan diatas, maka dirumuskanmasalah ialah apakah Debt to Equity Ratio (DER) dan Debt to Asset Ratio (DAR) berpengaruh secara simultan dan parsial terhadap nilai perusahaan yang tercermin dari PBV pada Industri Barang Konsumsi di Bursa Efek Indonesia periode 2013-2015.

\section{METODE}

Penelitian ini dilakukan dengan menggunakan laporan keuangan perusahaan manufaktur sektor barang konsumsi yang terdaftar di Bursa Efek Indonesia (BEI). Berdasarkan informasi yang diperoleh, jumlah perusahaan manufaktur sektor barang konsumsi yang terdaftar dari tahun 2013 sampai tahun 2015 adalah 36 perusahaan.

Penentuan sampel dalam penelitian ini berdasarkan pada metode purposive sampling, dimana sampel perusahaan dipilih berdasarkan pada kriteria tertentu. Jumlah sampel yang memenuhi kriteria dalam penelitian ini adalah sejumlah 32 perusahaaan.

Data yang digunakan dalam penelitian ini adalah data sekunder. Teknik pengumpulan datanya tersebut diperolehmelalui internet yang berupalaporan laba rugi, neraca tahunan industri manufaktur yang telah diaudit oleh akuntan profesional mulai tahun 2013 sampai tahun 2015 dan data harga saham.pada akhir Desember tahun yang bersangkutan dan studi kepustakaan, yaitu dengan mencari informasi-informasi tertulis yang berkaitan dengan penelitian ini.

Dalam penelitian ini, yang dijadikan sebagai variabel dependen adalah nilai perusahaan (Y). Sedangkan variabel independen dalam penelitian ini adalah Debt to Equity Ratio (DER) (X1) dan Debt to Asset Ratio (DAR) (X2).

Analisis data yang digunakan dalam penelitian ini meliputi analisis deskriptif, uji asumsi klasik, analisis regresi linier berganda, uji F dan uji t. Analisis data yang dimaksud dalam penelitian ini adalah kegiatan yang dikerjakan setelah data terkumpul semuanya, baik itu merupakan data yang berasal dari seluruh responden maupun data yang berasal dari sumbersumber yang lain, (Sugiyono, 2011:147). Berbagai macam analisis data tersebut akan dijelaskan sebagai berikut:

\section{Analisis Deskriptif}

Analisis deskriptif menurut penjelasan Sugiyono, (2011:147), 
merupakan analisis yang dilakukan melalui cara pendeskripsian dari sekumpulan data tanpa ada maksud untuk membuat kesimpulan secara umum.

2. Uji Asumsi Klasik meliputi:

Uji asumsi klasik dalam penelitian ini a. Uji Normalitas

Uji normalitas menurut penjelasan Nugroho, 2005:18 dalam Sujianto 2009, merupakan uji yang dilakukan untuk mengetahui apakah di dalam model analisis regresi, variabel terikat dan variabel bebasnya sudah terdistribusi secara normal atau belum. Uji ini dapat menggunakan 3 metode analisis. Analisis tersebut meliputi analisis histogram, analisis grafik normal probability plot dan analisis statistik OneSample Kolmogorov- Smirnov.

b. Uji Multikolinieritas

Multikolinearitas timbul sebagai akibat adanya hubungan kausal antara dua variabel bebas atau lebih atau adanya kenyataan bahwa dua variabel penjelas atau lebih bersama-sama dipengaruhi oleh variabel ketiga yang berada di luar model.Untuk mendeteksi adanya multikolinearitas, Nugroho dalam Sujianto (2009:79) menyatakan jika nilai Variance Inflation Factor (VIF)tidak lebih dari 10 maka model terbebas dari multikolinearitas. VIF adalah suatu estimasi berapa besar multikolinearitas meningkatkan varian pada suatu koefisien estimasi sebuah variabel penjelas.VIF yang tinggi menunjukkan bahwa multikolinearitas telah menaikkan sedikit varian pada koefisien estimasi, akibatnya menurunkan nilai t.

c. Uji Heterokedastisitas

Model yang baik adalah tidak terjadi heteroskedastisitas atau dengan kata lain heteroskedastisitas menunjukkan adanya varians yang tidak sama diantara anggota kelompok-kelompok data. Sedangkan yang diharapkan dalam suatu analisis parametrik adalah kondisi adanya homoskedastisitas.

Cara untuk mendeteksi ada tidaknya heteroskedastisitas adalah dengan melihat grafik plot antara nilai residu variabel dependen (SRESID) dengan nilai prediksi
(ZPRED) (Santoso, 2006). Dasar analisisnya: (a) Jika ada pola tertentu, seperti titik-titik yang membentuk pola yang teratur (bergelombang, melebar kemudian menyempit), maka mengidentifikasikan telah terjadi heteroskedastisitas. (b) Jika tidak ada pola yang jelas, serta titik-titik menyebar di atas dan di bawah angka pada sumbu Y, maka tidak terjadi heteroskedastisitas.

d. Uji Autokorelasi

Uji Autokorelasi adalah korelasi yang terjadi diantara anggota observasi yang terletak berderetan, biasanya terjadi pada time series.Menurut Makridakis, dkk dalam Sujianto (2009:80) untuk mendeteksi autokorelasi dapat dilakukan dengan uji Durbin Watson (DW) dengan ketentuan sebagai berikut:

1. $1.65<\mathrm{DW}<2.35$ maka tidak ada autokorelasi.

2. $1.21<\mathrm{DW}<1.65$ atau $2.35<\mathrm{DW}$ $<2.79$ maka tidak dapat disimpulkan.

3. $\mathrm{DW}<1.21$ atau $\mathrm{DW}>2.79$ maka terjadi autokorelasi.

3. Analisis regresi linier berganda

Untuk menganalisis faktor-faktor yang mempengaruhi nilai perusahaan digunakan analisis regresi linear berganda, yaitu suatu metode statistik dimana variabel terikat dihubungkan atau dijelaskan oleh lebih dari satu variabel bebas. Bentuk persamaannya adalah sebagai berikut:

$\mathrm{Y}=\mathrm{a}+\mathrm{b} 1 \mathrm{X} 1+\mathrm{b} 2 \mathrm{X} 2+\mathrm{e}$

Dimana:

$\mathrm{Y} \quad=$ Nilai Perusahaan

$\mathrm{a}=$ Konstanta

b1,b2 = Nilai koefisien regresi dari masingmasing variabel bebas (independen)

$\mathrm{X} 1=$ Variabel DAR

$\mathrm{X} 2=$ Variabel DER

$\mathrm{E}=$ Standard Error

Apabila nilai koefisien struktur modal yang diukur dengan Debt to Equity Ratio (DER) dan Debt to Asset Ratio (DAR) dan signifikan, maka akan menunjukkan bahwa struktur modal berpengaruh terhadap nilai perusahaan.

4. Uji Statistik F atau Uji Simultan

p.ISSN: $2407-800 \mathrm{X}$

e.ISSN: $2541-4356$ 
Uji simultan menurut penjelasan merupakan uji yang digunakan untuk mengetahui apakah variabel bebas (independen) yang dimasukkan dalam model analisis regresi mempunyai pengaruh secara bersama-sama terhadap variabel terikatnya (dependen). (Ghozali, 2009:16). Jika nilai Fhitung > Ftabel dan nilai signifikansinya $<0,05$ maka terdapat pengaruh secara bersama-sama antar variabel bebas terhadap variabel terikatnya.

5. Uji Statistik t atau Uji Parsial

Uji parsial menurut penjelasan Kuncoro, (2009:238), merupakan uji yang dilakukan untuk mengetahui apakah di dalam model analisis regresi terdapat pengaruh variabel bebas (independen) secara individual terhadap variabel terikatnya (dependen). Terdapat pengaruh secara parsial jika nilai thitung lebih besar dibandingkan dengan nilai ttabel dan nilai signifikansinya berada di bawah 0,05 .

\section{HASIL}

Dari hasil analisis regresi dapat diformulasikan persamaan regresi linear berganda dalam model persamaan regresi sebagai berikut:

$\mathrm{Y}=0.413+0.815 \mathrm{X} 1-0.595 \mathrm{X} 2+\mathrm{e}$

Berikut interpretasi besarnya nilai koefisien dari persamaan regresi di atas:

a. Koefisien regresi variabel DER (X1) $=0.815$

Hal ini berarti, bahwa variabel DER memiliki hubungan yang berbanding lurus terhadap nilai perusahaan dimana setiap ada kenaikan sebesar satu satuan dari variabel DER, nilai perusahaan akan mengalami kenaikan sebesar 0.815 begitu juga sebaliknya setiap ada penurunan sebesar 0.815 dengan adanya asumsi yaitu variabel bebas yang lain dari model regresi dalam penelitian ini adalah tetap.

b. Koefisen regresi variabel DAR (X2) $=-0.595$

Hal ini berarti, bahwa variabel DAR memiliki hubungan yang berbanding terbalik terhadap nilai perusahaan dimana setiap ada kenaikan sebesar satu satuan dari variabel DAR, nilai perusahaan akan mengalami penurunan sebesar 0.595 begitu juga sebaliknya setiap ada penurunan sebesar satu satuan dari variabel DAR maka nilai perusahaan akan mengalami kenaikan sebesar 0.595 dengan adanya asumsi variabel bebas yang lain dari model regresi dalam penelitian ini adalah tetap.

\section{PEMBAHASAN}

Penelitian menunjukkan bahwa struktur modal (variabel DER dan DAR) berpengaruh terhadap nilai perusahaanyang diukurdengan PBVdan memiliki nilai koefisien positif. Hasil perhitungan menunjukkan bahwa nilai dari Fhitungadalah sebesar 6.885 dimana mempunyai nilai yang lebih besar dibandingkan dengan nilaidari Ftabelyaitu sebesar 3,09 dan nilai signifikansi 0,002 lebih kecil dari nilai $\alpha(0,05)$. Hal ini mengindikasikan bahwa seluruh variabel independen yaitu variabel DER dan variabel DAR berpengaruh secara simultan terhadap variabel dependen yaitu nilai perusahaan yang diukur dengan PBV.

Tujuan akhir suatu perusahaan dari struktur modal yang optimal adalah struktur yang memaksimalkan harga dari saham perusahaan, (Brigham dan Houston, 2010). Oleh karena itu struktur modal yang tidak baik dihindari agar tidak menimbulkan beban yang akan ditanggung perusahaan karena struktur modal yang dapat memaksimumkan nilai perusahaan merupakan struktur modal yang mempunyai biaya modal yang minimum.

Hasil penelitian inididukung olehtrade off theory memprediksi adanya hubungan yang positif terhadap nilai perusahaan. Tetapi bertolak belakang dengan teori Modigliani dan Miller (1958) yang menyatakan nilai perusahaan yang menggunakan hutang sama dengan nilai perusahaan yang tidak menggunakan hutang artinya MM tidak mengakui adanya pengaruh struktur modal terhadap nilai perusahaan.

Hasil penelitian ini mendukung hasil penelitian Kusumajaya (2011), Chowdhury and Paul (2010), dan Safrida (2008) menunjukkan bahwa struktur modal mempunyai pengaruh terhadap nilai

$$
\text { p.ISSN: 2407-800X e.ISSN: 2541-4356 }
$$


perusahaan. Namun bertolak belakang dengan hasil penelitian Savitri (2012) yang menyatakan bahwa struktur modal tidak mempengaruhi nilai perusahaan pada kondisi terdapatnya ketidakpastian lingkungan. Investor lebih melihat prospek perusahaan daripada hutang perusahaan dan penambahan jumlah saham utama cara yang tepat untuk meningkatkan nilai perusahaan.

Hasil pengujian variabel DER menunjukkan thitung < ttabel yaitu 3.398 $<1.98580$ dengan nilai signifikansi 0,001 lebih kecil dari 0,05. Hal ini menunjukkan $\mathrm{H} 0$ ditolak dan $\mathrm{H} 2$ diterima yang berarti bahwa DER memiliki pengaruh secara parsial terhadap nilai perusahaan yang diukur dengan PBV. Artinya, informasi perubahan DER yang sebagaimana bisa diperoleh dari laporan keuangan berpengaruh pada keputusan atas harga saham di pasar modal Indonesia, dimana hal ini juga akan berpengaruh terhadap nilai perusahaan karena bagi perusahaan yang sudah go public nilai perusahaannya akan tercermin dari nilai pasar sahamnya (Rovita dkk, 2012).

Pengujian terhadap variabel DAR menunjukkan thitung > ttabel yaitu -1,106 > 1.98580 dengan nilai signifikansi 0,271 lebih besar dari 0,05. Hal ini menunjukkan $\mathrm{H} 2$ ditolak dan $\mathrm{H} 0$ diterima yang berarti bahwa DAR tidak memiliki pengaruh secara parsial terhadap nilai perusahaan yang diukur denganPBV. Artinya, informasi perubahan DAR yang sebagaimana bisa diperoleh dari laporan keuangan tidak berpengaruh pada keputusan atas harga saham di pasar modal Indonesia, dimana hal ini juga tidak berpengaruh terhadap nilai perusahaan karena bagi perusahaan manufaktur sektor barang konsumsi tidak terlalu terfokus pada pengalokasian hutang dalam pembiayaan aktiva, melainkan bagaimana beban yang timbul atas hutang tersebut dapat ditutup dengan tetap menerima bagian keuntungan yang besar (Salim, 2015).

\section{SIMPULAN}

Berdasarkan hasil analisis dan pembahasan, maka diperoleh beberapa kesimpulan sebagai berikut: Nilai dari variabel bebas yaitu variabel DER dan DAR adalah sebesar 6.885. Nilai Fhitung tersebut memiliki nilai yang lebih besar jika dibandingkan dengan nilai Ftabel-nya yang memiliki nilai sebesar 3,09. Nilai signifikansinya lebih kecil dari 0,05 yaitu sebesar 0.002 sehingga variabel DER dan DAR secara simultan memiliki pengaruh terhadap nilai perusahaan pada perusahaan manufaktur sector barang konsumsi yang terdaftar di BEI periode 2013-2015. Variabel DER merupakan variabel satusatunya dari variabel bebas dalam penelitian ini yang secara parsial memiliki pengaruh terhadap nilai perusahaan pada perusahaan manufaktur sector barang konsumsi yang terdaftar di BEI periode 2013-2015 karenat-hitung nya yaitu sebesar3.398 bernilai lebih besar jika dibandingkan dengan nilai t-tabel nya yaitu sebesar 1.98580 dengan nilai signifikansi yang lebih kecil dari 0,05 yaitu sebesar 0,001 .

\section{DAFTAR RUJUKAN}

Brigham and Houston.,2010., Dasar-Dasar Manajemen Keuangan., Edisi 11., Salemba Empat., Jakarta.

Chowdhury, A. and Paul, S., 2010., Impact of Capital Structure on Firm's Value., Evidence from Bangladesh Journal., ISSN 1804-1205.

Ghozali., 2009., Aplikasi Analisis Multivariat Dengan Program SPSS., Badan Penerbit Universitas Diponegoro., Semarang.

Harjito, A. dan Martono., 2010., Manajemen Keuangan., Edisi Kedua., Ekonisia., Yogyakarta.

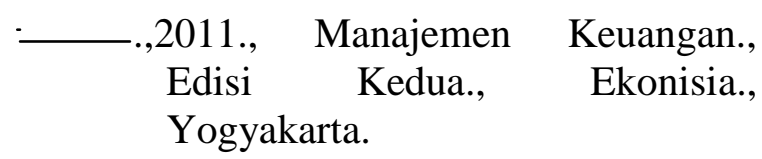


Kuncoro, Mudrajad., 2009.,Metode Riset Untuk Bisnis dan Ekonomi., Erlangga., Jakarta.

Kusumajaya, Dewa., 2011., Pengaruh Struktur Modal dan Pertumbuhan Perusahaan terhadap Profitabilitas dan Nilai Perusahaan pada Perusahaan Manufaktur di Bursa Efek Jakarta., Tesis.

Kusnaeni, Diyah., 2012., Pengaruh Struktur Modal terhadap Nilai Perusahaan pada Industri Barang Konsumsi di Bursa Efek Indonesia., Tesis.

Rovita dkk.., 2014., Pengaruh Struktur Modal terhadap Nilai Perusahaan (Studi pada Sektor Pertambangan yang Terdaftar di BEI 2009-2012., Jurnal Administrasi Bisnis., Vol.17., No.1.

Safrida, Eli., 2008., Pengaruh Struktur Modal dan Pertumbuhan Perusahaan Terhadap Nilai Perusahaan Pada Perusahaan Manufaktur di Bursa Efek Jakarta., Tesis. dan Real Estate yang erdaftar di Bursa Efek Indonesia., Jurnal Perbanas Review Vol. 1., No. 1

Santoso., 2006., Menguasai Statistik di Era Informasi dengan SPSS 15.,Elex Media Komputindo ., Jakarta.

Savitri, Enni., 2012., Variabel Anteseden Dari Struktur Modal: Dampaknya Terhadap Nilai Perusahaan., Disertasi.

Sugiyono., 2011., Metode Penelitian Kuantitatif Kualitatif dan R\&D.,Alfabeta., Bandung.

Sujianto, Agus Eko., 2009., Aplikasi Statistik dengan SPSS 16.0., Prestasi Pustaka., Jakarta.

Susanti, Rika., 2010., Analisis FaktorFaktor yang Berpengaruh Terhadap Nilai Perusahaan., Skripsi.
Salim, Jihan., 2015., Pengaruh Leverage terhadap ROE Perusahaan Property 